\title{
PENGARUH RASIO PROFITABILITAS, RASIO SOLVABILITAS, DAN RASIO LIKUIDITAS TERHADAP RETURN SAHAM PERUSAHAAN PROPERTI DAN REAL ESTATE YANG TERDAFTAR DALAM INDEKS SAHAM SYARIAH INDONESIA (ISSI) PERIODE 2011 - 2014
}

\author{
Novia Eka Fitri \\ Program Studi S-1 Ekonomi Islam Fakultas Ekonomi dan Bisnis Universitas Airlangga \\ Email : noviaekafitri@gmail.com \\ Leo Herlambang \\ Departemen Ekonomi Syariah Fakultas Ekonomi dan Bisnis Universitas Airlangga \\ Email : leo.herlambang@gmail.com
}

\begin{abstract}
:
This study aims to determine the effect of Return of Asset (ROA), Debt to Equity Ratio (DER), and Current Ration (CR) on stock return partially and simultaneously. The objects of the study are Property and Real Estate Company which registered in Indonesia Sharia Stock Index (ISSI) for four years, 2011-2014. This study used quantitative research. The writer used literature study and gathered secondary data for technique of data collection.

This study finds that partially Return of Asset (ROA) significantly affects on stock return, while Debt to Equity Ratio (DER) and Current Ratio (CR) are not significantly affect on stock return. SimultaneouslyReturn on Assets (ROA), Debt to Equity Ratio (DER) and Current Ration (CR) do not significantly affect on stock return.
\end{abstract}

Keywords :Return on Asset (ROA), Debt to Equity Ratio (DER), Current Ratio (CR), Stock Return.

\section{PENDAHULUAN}

\section{Latar Belakang}

Dalam sebuah kaidah Figh, semua aktivitas muamalah adalah boleh, kecuali yang diharamkan. Investasi sebagai suatu aktivitas muamalah tidak terlepas dari kaidah Fiqh tersebut. Islam menganjurkan umatnya untuk mengembangkan harta kekayaan. Mendiamkan harta secara tidak produktif adalah perbuatan yang tidak dibenarkan. "Larangan mendiamkan harta kekayaan tersebut dilandasi oleh prinsip Islam yang menghendaki adanya perputaran harta kekayaan secara lebih merata. Namun, bukan berarti penggunaan harta tersebut sangat bebas, melainkan tetap harus memperhatikan rambu - rambu yang sesuai koridor syariah." (Huda, 2007:40)
Kegiatan investasi telah lama dikenal oleh masyarakat, baik melalui media massa, seperti : kabar, televisi, dan radio. Investasi dapat dilakukan oleh berbagai pihak, antara lain : kreditur, bankers, para investor, dan pemerintah dimana perusahaan berada. Investasi merupakan penanaman sejumlah dana pada waktu sekarang dengan tujuan dana tersebut akan aman atau meningkat nilainya atau menghasilkan return di waktu yang akan datang.

Menurut Restiana (2007:01) pada objek yang memiliki resiko, yakni investasi pada objek yang return aktualnya dimasa depan mengandung unsur ketidakpastian, sedangkan investasi pada objek yang bebas resiko merupakan investasi pada obyek yang mempunyai

1) Jurnal ini merupakan bagian dari skripsi dari Novia Eka Fitri, NIM : 041114100 , yang diuji pada 12 Februari 2016. 
Fitri, et al/Jurnal Ekonomi Syariah Teori dan Terapan Vol. 3 No. 8 Agustus 2016: 625-642; PENGARUH RASIO PROFITABILITAS, RASIO SOLVABILITAS, DAN RASIO LIKUIDITAS TERHADAP RETURN SAHAM PERUSAHAAN PROPERTI DAN REAL ESTATE YANG TERDAFTAR DALAM INDEKS SAHAM SYARIAH INDONESIA (ISSI) PERIODE 2011 - 2014

tingkat return dimasa depan sudah dapat dipastikan pada saat ini.

Menurut Hanani Ika (2011:10), dalam perspektif Islam Investasi merupakan suatu kegiatan muamalah yang dianjurkan, karena ketika berinvestasi harta yang kita miliki menjadi lebih produktif ketimbang sebelumnya dan juga mendatangkan manfaat bagi orang lain serta merupakan bentuk dari ekonomi syariah. Seluruh harta yang dimiliki oleh setiap muslim terdapat zakat yang harus dikeluarkan serta dibagikan terhadap muslim yang lain yang membutuhkan. Jika harta umat muslim didiamkan saja maka dari waktu ke waktu harta mereka akan habis. Maka salah satu hikmah dari zakat yaitu mendorong umat muslim untuk berinvestasi. Seperti dalam (QS. Al - Hadid : 7 ) :

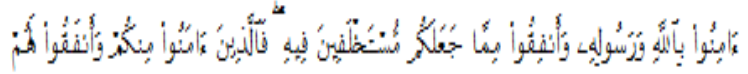

(aminoo billahi warasoolihi waanfiqoo mimma jaalakum mustakhlafeena feehi faallatheena amanoo minkum waanfaqoo lahum ajrun kabeerun)

Artinya : "Berimanlah kamu kepada Allah dan Rasul-Nya dan nafkahkanlah sebagian dari hartamu yang Allah telah menjadikan kamu menguasainya. Maka orang-orang yang beriman di antara kamu dan menafkahkan (sebagian) dari hartanya memperoleh pahala yang besar." (Al - Qur'an Departemen Agama Rl, 2007 : 901)

$$
\text { Kewajiban melakukan }
$$

pengembangan harta kekayaan melalui investasi sangat ditekankan dalam Islam. Uang di satu rekening tabungan, besar kemungkinan inflasi akan menggerus nilai vang. Selama kurun waktu tertentu, nilai vang akan berkurang dan secara financial akan lebih buruk dimasa depan. Mengembangkan nilai vang dapat menghindari efek negative inflasi, merupakan alasan utama berinvestasi. (Daud, 2012:283)

Berbagai macam cara yang dapat dilakukan pemilik modal dalam melakukan investasi, salah satunya dengan melakukan investasi di pasar modal. Dalam hal ini "pasar modal didefinisikan sebagai suatu tempat berlangsungnya kegiatan yang berkaitan dengan penawaran umum dan perdagangan efek, perusahaan public yang berkaitan dengan efek yang diterbitkannya, serta lembaga dan profesi yang berkaitan dengan efek" (UU No. 8/1995 Tentang Pasar Modal).

Setiap perusahaan go public didirikan dengan harapan bahwa perusahaan tersebut dapat mempertahankan kelangsungan usahanya, berkembang dengan pesat untuk jangka waktu yang panjang. Pada awal pendirian perusahaan, umumnya telah dipandang cukup untuk dapat bertahan dalam aktivitas usahanya namun dengan berjalannya waktu terjadi persaingan usahan yang semakin meningkat. Sehingga, diperlukan strategi strategi yang tidak hanya membuat perusahaan bertahan namun mampu membuat perusahaan tersebut 
Fitri, et al/Jurnal Ekonomi Syariah Teori dan Terapan Vol. 3 No. 8 Agustus 2016: 625-642; PENGARUH RASIO PROFITABILITAS, RASIO SOLVABILITAS, DAN RASIO LIKUIDITAS TERHADAP RETURN SAHAM PERUSAHAAN PROPERTI DAN REAL ESTATE YANG TERDAFTAR DALAM INDEKS SAHAM SYARIAH INDONESIA (ISSI) PERIODE 2011 - 2014

memenangkan persaingan bisnis yang semakin ketat.

Dalam konteks manajemen

investasi, return, atau tingkat keuntungan merupakan imbalan yang diperoleh dari investasi. "Return ini dibedakan menjadi dua, pertama : return yang telah terjadi(actual return) yang dihitungberdasarkan data historis, dankedua : return yang diharapkan (expected return) akandiperoleh investor dimasamendatang." (Halim,2003)

Tingkat keuntungan (return) merupakan rasio antara pendapatan investasi selama beberapa periode dengan jumlah dana yang diinvestasikan. Pada umumnya investor mengharapkan keuntungan yang tinggi dengan resiko yang serendah mungkin, sehingga para investor berusaha menentukan tingkat keuntungan tingkat keuntungan investasi yang optimal dengan menentukan konsep investasi yang memadai. Konsep ini penting karena tingkat keuntungan yang diharapkan dapat diukur.

Transaksi jual - beli saham pada dasarnya adalah transaksi yang diperbolehkan dalam Islam, karena saham dipahami sebagai sebuah bukti kepemilikan atas perusahaan tertentu yang berbentuk asset. (Huda,2007:65) Bukan dipahami sebagai utang perusahaan kepada pemilik modal. Namun, sebagai investor muslim, tetap harus memilih menginvestasikan modal pada perusahaan yang menjalankan usahanya sesuai dengan prinsip syariah.
Investasi pada sekuritas baik konvensional maupun syariah bersifat likuid atau mudah dirubah sehingga penting bagi perusahaan untuk selalu memperhatikan kepentingan para pemilik modal dengan jalan memaksimalkan nilai perusahaan, karena nilai perusahaan merupakan ukuran keberhasilan atas pelaksanaan fungsi - fugsi keuangannya.

Analisis kinerja keuangan perusahaan dapat dilakukan dengan memanfaatkan laporan keuangan. Informasi laporan keuangan digunakan dan memiliki fungsi sebagai dasar pengambilan keputusan, baik oleh investor maupun calon investor. Adapun kinerja keuangan suatu perusahaan dapat dianalisis menggunakan rasio keuangan. Analisis rasio dapat digunakan untuk membimbing investor dan kreditor unuk membuat keputusan atau pertimbangan tentang pencapaian perusahaan dan prospek dimasa datang. Secara umun rasio keuangan ada 4, yaitu : rasio profitabilitas, rasio solvabilitas, rasio likuiditas, dan rasio aktivitas. Selama ini laba akuntansi selalu menjadi focus perhatian dalam menilai kinerja suatu perusahaan. Laba atau keuntungan merupakan hasil dari kebijaksanaan yang diambil oleh manajemen. Rasio keuntungan dipakai untuk mengukur seberapa besar tingkat keuntungan yang dapat diperoleh perusahaan. Semakin besar tingkat keuntungan menunjukkan semakin baik manajemen dalam mengelola perusahaan. 
Fitri, et al/Jurnal Ekonomi Syariah Teori dan Terapan Vol. 3 No. 8 Agustus 2016: 625-642; PENGARUH RASIO PROFITABILITAS, RASIO SOLVABILITAS, DAN RASIO LIKUIDITAS TERHADAP RETURN SAHAM PERUSAHAAN PROPERTI DAN REAL ESTATE YANG TERDAFTAR DALAM INDEKS SAHAM SYARIAH INDONESIA (ISSI) PERIODE 2011 - 2014

Kinerja keuangan adalah usaha formal yang telah dilakukan oleh perusahaan yang dapat mengukur keberhasilan perusahaan dalam menghasilkan laba, sehingga dapat melihat prospek, pertumbuhan, dan potensi perkembangan baik perusahaan dengan mengandalkan sumber daya yang ada. Suatu perusahaan dapat dikatakan berhasil apabila telah mencapai standart dan tujuan yang telah ditetapkan.

Pengukuran kinerja digunakan untuk melakukan perbaikan diatas kegiatan operasionalnya agar dapat bersaing dengan perusahaan lain. Analisis kinerja keuangan merupakan proses pengkajian secara kritis terhadap review data, menghitung, mengukur, menginterpretasikan, dan memberi solusi terhadap keuangan perusahaan pada suatu periode tertentu. Kinerja keuangan dapat dinilai dengan beberapa alat analisis. Berdasarkan tekniknya, menurut Jumingan (2006:242) analisis keuangan dapat dibedakan menjadi 8 macam, yaitu : Analisis Perbandingan Laporan Keuangan, Analisis Tren (tendensi posisi), Analisis Persentase per Komponen (common size), Analisis Sumber dan Penggunaan Modal kerja, Analisis Sumber dan Penggunaan kas, Analisis Rasio Keuangan, Analisis Laba Kotor, dan Analisis Break Even.

Berbagai macam analisis kinerja keuangan, analisis yang sering digunakan untuk mengukur keberhasilan perusahaan dalam menghasilkan laba yaitu analisis rasio kevangan. Dimana didalam analisis laporan keuangan terdapat berbagai macam rasio, yaitu : Rasio Profitabilitas/Rentabilitas, Rasio Aktivitas, Rasio Likuiditas, dan Rasio Solvabilitas. Contoh - contoh rasio keuangan ada berbagai macam, seperti : ROA (Return On Asset), CR (Current Asset), DER (Debt to Equity Ratio), dan lain - lain.

ROA (Return On Asset) merupakan bentuk dari rasio profitabilitas yang mengukur kemampuan perusahaan dalam menghasilkan laba dengan menggunakan total aktiva yang ada. Setelah biaya - biaya modal (biaya yang digunakan mendanai aktiva) dikeluarkan dari analisis. Bahkan Ang (1997) mengatakan bahwa Return On Asset (ROA) merupakan rasio yang terpenting di antara rasio profitabilitas yang ada untuk memprediksi return saham.

Rasio solvabilitas yang sering dikaitkan dengan return saham yaitu Debt To Equity Ratio (DER). Debt To Equity Ratio (DER) mencerminkan kemampuan perusahaan dalam memenuhi seluruh kewajibannya yang ditunjukkan oleh berapa bagian dari modal sendiri yang digunakan untuk membayar hutang. Debt To Equity Ratio (DER) juga memberikan jaminan tentang seberapa besar hutanghutang perusahaan dijamin modal sendiri. Debt To Equity Ratio (DER) akan mempengaruhi kinerja perusahaan dan menyebabkan apresiasi dan depresiasi harga saham. Menurut Sofiati (2000) dalam Suwandi (2003) menyatakan bahwa penggunaan hutang oleh suatu 
Fitri, et al/Jurnal Ekonomi Syariah Teori dan Terapan Vol. 3 No. 8 Agustus 2016: 625-642; PENGARUH RASIO PROFITABILITAS, RASIO SOLVABILITAS, DAN RASIO LIKUIDITAS TERHADAP RETURN SAHAM PERUSAHAAN PROPERTI DAN REAL ESTATE YANG TERDAFTAR DALAM INDEKS SAHAM SYARIAH INDONESIA (ISSI) PERIODE 2011 - 2014

perusahaan akan membuat risiko yang ditanggung pemegang saham meningkat. Ketika terdapat penambahan jumlah hutang secara absolut maka akan menurunkan tingkat solvabilitas perusahaan, yang selanjutnya akan berdampak dengan menurunnya nilai (return) saham perusahaan.

Likuiditas perusahaan merupakan kemampuan finansial dari suatu perusahaan untuk memenuhi kewajiban finansial pada saat ditagih. Perusahaan yang mampu memenuhi kewajiban keuangannya pada saat ditagih berarti perusahaan tersebut dalam keadaan likuid, sebaliknya jika perusahaan tidak mampu memenuhi kewajiban finansialnya pada saat ditagih maka perusahaan itu dalam keadaan tidak likuid. Bagi perusahaan, likuid merupakan masalah yang sangat penting karena mewakili kepentingan perusahaan dalam berhubungan dengan pihak lain, baik pihak intern ataupun pihak ekstern. Adapun rasio likuiditas yang digunakan dalam penelitian ini adalah Current ratio (CR). Current Ratio (CR) merupakan rasio perbandingan antara aktiva lancar dan hutang lancar (Cahyati, 2006). Semakin besar current ratio yang dimiliki menunjukkan besarnya kemampuan perusahaan dalam memenuhi kebutuhan operasionalnya terutama modal kerja yang sangat penting untuk menjaga perfomance kinerja perusahaan yang pada akhirnya mempengaruhi performance harga saham. Hal ini dapat memberikan keyakinan kepada investor untuk memiliki saham perusahaan tersebut sehingga dapat meningkatkan return saham.

Selain JII (Jakarta Islamic Index) Bursa Efek Indonesia juga meluncurkan ISSI (Indeks Saham Syariah Indonesia) pada tanggal 12 Mei 2011, indeks ini mencerminkan pergerakan saham saham yang masuk dalam Daftar Efek Syariah (DES) yang dikeluarkan Bapepamdan LK. Tahun dasar perhitungan ISSI adalah awal penerbitan Daftar Efek Syariah (DES) pada Desember 2007. Dengan metode penghitungan menggunakan rata - rata tertimbang dari kapitalisasi pasar. (sumber : Bursa Efek Indonesia, diakses 24 Juni 2015)

Sebelumnya, Bursa Efek Indonesia (BEI) meluncurkan fatwa No.80 tentang Penerapan Prinsip Syariah dalam Mekanisme Perdagangan Efek Bersifat Ekuitas di Pasar Regular Bursa Efek yang telah disahkan oleh Dewan Syariah Nasional Majelis Ulama Indonesia (DSN MUI) pada tanggal 08 Maret 2011. Dengan adanya pengesaha fatwa tersebut, maka penyelenggaraan perdagangan efek di BEI telah memiliki dasar atau hukum fiqih yang kuat bahwa mekanisme lelang berkelanjutan (continous auction) yang digunakan BEI dalam transaksi efek bersifat ekuitas di pasar reguler sesuai dengan prinsip syariah. Pada tahun 2014 ada 303 perusahaan berbasis syariah yang tergabung di dalam ISSI secara garis besar dibagi menjadi 2 kategori portofolio saham, yaitu portofolio saham syariah 
Fitri, et al/Jurnal Ekonomi Syariah Teori dan Terapan Vol. 3 No. 8 Agustus 2016: 625-642; PENGARUH RASIO PROFITABILITAS, RASIO SOLVABILITAS, DAN RASIO LIKUIDITAS TERHADAP RETURN SAHAM PERUSAHAAN PROPERTI DAN REAL ESTATE YANG TERDAFTAR DALAM INDEKS SAHAM SYARIAH INDONESIA (ISSI) PERIODE $2011-2014$

yang stabil listing dan portofolio saham syariah yang tidak stabil listing. Indeks saham Syariah Indonesia (ISSI) memiliki 8 sektor, yaitu sektor pertnian, sektor pertambangan, sektor industri dasar, sektor aneka industri, sektor barang dan konsumsi, sektor properti dan real estate, sektor infrastruktur, dan sektor perdagangan.

Menurut Panangian Simanukalit seorang pakar properti, bahwa harga investasi properti di Indonesia memiliki harga properti yang murah dengan return yang besar dibanding negara lain di Asia. Selain itu, perkembangan sektor ini diperkirakan cerah antara tahun 2008 2014 karena fakor ekonomi di Indonesia lebih besar dibandingkan dengan pertumbuhan ekonomi dunia. Jumlah penduduk di Indonesia terbesar ke-4 didunia menyebabkan kebutuhan akan perumahaan semakin diminati. Dengan adanya krisis di Eropan dan di Amerika tidak membawa pengaruh terhadap pertumbuhan sektor properti di Indonesia.

\section{LANDASAN TEORI}

Islam mengajarkan semua aspek kehidupan manusia, baik hubungan manusia dengan Allah SWT dalam ibadah maupun hubungan antar sesama manusia dalam konsep muamalah. Didalam pengertian ini ibadah dan muamalah tidak dapat dipisahkan, maka keduanya harus dijalankan secara bersamaan.

Pelaksanaan ekonomi adalah sesuatu bagian dari ajaran muamalah. Pelaksanaan ataupun pemenuhan ekonomi harus dilakukan sesuai dengan nilai-nilai Islam yang telah ada. Nilai-nilai Islam didasarkan pada sumber hukum yaitu Al-Quran dan Hadits. Semua kegiatan keuangan Islam adalah bagian dari Ekonomi Islam. Ekonomi Islam merupakan ekonomi yang berdasarkan kepada nilai-nilai Islam sehingga tidak bisa lepas dari fungsi-fungsi syariah yang ada di dalam dasar hukumnya.

$$
\text { Menurut Ryandono }
$$
menyimpulkan definisi Syariah sebagai berikut :

Syariah adalahhukum yang ditetapkan dan diwahyukan oleh Allah kepada rasul-Nya yang mengatur aspek etika atau akhlak manusia kepada Allah (ibadah), manusia kepada manusia lain (muamalah) dan manusia kepada alam sekitarnya sehingga kehidupan di dunia ini menjadi teratur, baik, dan mudah. Sementara syariah Islam berarti aturan atau ajaran yang berasal dari Allah dan diturunkan kepada Rasulullah Muhammad saw. Untuk disampaikan kepada umat manusia agar mereka mencapai kehidupan yang sejahtera, damai bahagia, dan selamat di dunia dan akhirat.

Tujuan syariah menurut Imam Ghazaali dalam Ryandono (2009:25) adalah

tujuan syariah yang paling utama yaitu memelihara kesejahteraan manusia yang meliputi perlindungan iman, kehidupan sosial, akal, keturunan, dan harta benda mereka. Apa saja yang menjamin terlindungnya lima perkara ini merupakan kemaslahatan bagi manusia.

Islam ingin memberikan jaminan kebahagian dan keselamatan bagi seluruh umatnya sehingga menetapkan berbagai aturan yang rinci mengenai muamalah, salah satunya adalah prinsip- 
Fitri, et al/Jurnal Ekonomi Syariah Teori dan Terapan Vol. 3 No. 8 Agustus 2016: 625-642; PENGARUH RASIO PROFITABILITAS, RASIO SOLVABILITAS, DAN RASIO LIKUIDITAS TERHADAP RETURN SAHAM PERUSAHAAN PROPERTI DAN REAL ESTATE YANG TERDAFTAR DALAM INDEKS SAHAM SYARIAH INDONESIA (ISSI) PERIODE 2011 - 2014

prinsip syariah Islam dalam kegiatan ekonomi. Menurut Rivai, dkk (2010:113) prinsip ini berdasarkan pada:

1. Pelarangan atas bunga (riba)

Ayat Al-Quran yang melarang menggunakan riba Q.S Al-Baqarah ayat 278 :

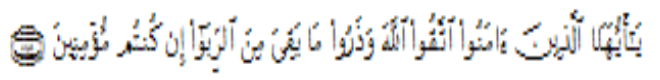

(yō ayyuhāalladzīna āmanū ittaqūallāha wadzarū mā baqiya mina alrribā in kuntum mu'minīna)

Artinya: "Hai orang-orang yang beriman, bertakwalah kepada Allah dan tinggalkan sisa riba (yang belum dipungut) jika kamu orangorang yang beriman." (AI - Qur'an Departemen Agama Rl, 2007: 69)

Firman Allah yang akan memberikan siksa atau Azab bagi orang-orang yang memakan riba Q.S An-Nisa ayat 161 :

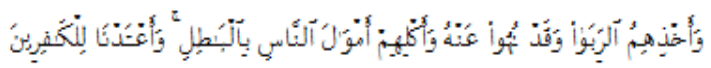

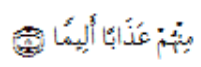

(wa-akhdzihimu alrribā waqad nuhū 'anhu wa-aklihim amwāla alnnāsi bialbāthili wa-a'tadnā lilkāfirīna minhum 'adzāban alīmān)

Artinya: "dan disebabkan mereka memakan riba, padahal sesungguhnya mereka telah dilarang daripadanya, dan karena mereka memakan harta benda orang dengan jalan yang batil. Kami telah menyediakan untuk orangorang yang kafir di antara mereka itu siksa yang pedih." (Al - Qur'an Departemen Agama RI, 2007: 150)

2. Mempergunakan transaksi yang diperbolehkan (halal) dan menghindari transaksi yang dilarang (haram)
Ayat Al-Quran yang menjelaskan tentang halal dan haram Q.S Yunus ayat 59 :

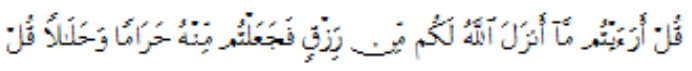

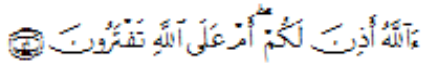

(qul ara-aytum māanzala allāhu lakum min rizqin faja'altum minhu harāman wahalālan qul āllāhu adzina lakum am 'alāallāhi taftarūna)

Artinya: Katakanlah: "Terangkanlah kepadaku tentang rezki yang diturunkan Allah kepadamu, lalu kamu jadikan sebagiannya haram dan (sebagiannya) halal". Katakanlah: "Apakah Allah telah memberikan izin kepadamu (tentang ini) atau kamu mengada-adakan saja terhadap Allah ?" ( Al - Qur'an Departemen Agama Rl, 2007 : 315)

3. Pelarangan dalam kontrak yang mengandung ketidakpastian (gharar)

Ayat Al-Quran yang menjelaskan tentang halal dan haram Q.S Al - Baqarah ayat 188 :

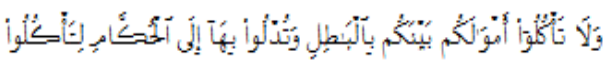

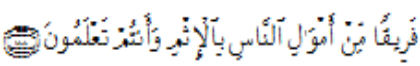

(walā ta'kulū amwālakum baynakum bialbāthili watudlū bihā ilāalhukkāmi lita'kulū farīqan min amwāli alnnāsi bial-itsmi wa-antum ta'lamūna)

Artinya: "Dan janganlah sebahagian kamu memakan harta sebahagian yang lain di antara kamu dengan jalan yang bathil dan (janganlah) kamu membawa (urusan) harta itu kepada hakim, supaya kamu dapat memakan sebahagian daripada harta benda orang lain itu dengan (jalan berbuat) dosa, padahal kamu mengetahui." (Al - Qur'an Departemen Agama Rl, 2007 : 46)

4. Termasuk spekulasi atas perjudian (maisir) 
Fitri, et al/Jurnal Ekonomi Syariah Teori dan Terapan Vol. 3 No. 8 Agustus 2016: 625-642; PENGARUH RASIO PROFITABILITAS, RASIO SOLVABILITAS, DAN RASIO LIKUIDITAS TERHADAP RETURN SAHAM PERUSAHAAN PROPERTI DAN REAL ESTATE YANG TERDAFTAR DALAM INDEKS SAHAM SYARIAH INDONESIA (ISSI) PERIODE 2011 - 2014

Ayat Al-Quran yang menjelaskan tentang halal dan haram Q.S Al - Maidah ayat 90 :

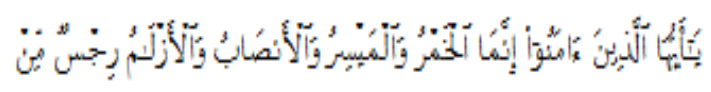

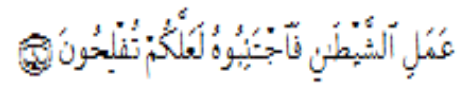

(yā ayyuhāalladzīna āmanū innamāalkhamru wālmaysiru wālanshābu wāl-azlāmu rijsun min 'amali alsysyaythāni faijtanibūhu la'allakum tuflihūna)

Artinya: "Hai orang-orang yang beriman, sesungguhnya (meminum) khamar, berjudi, (berkorban untuk) berhala, mengundi nasib dengan panah, adalah termasuk perbuatan syaitan. Maka jauhilah perbuatanperbuatan itu agar kamu mendapat keberuntungan." (Al - Qur'an Departemen Agama RI, 2007: 176)

5. Pembayaran zakat

Ayat Al-Quran yang menjelaskan tentang halal dan haram Q.S Al - Baqarah ayat 43 :

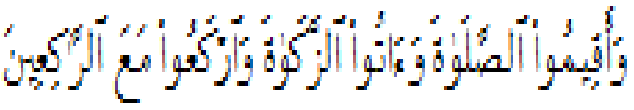

(wa-aqīmūalshshalāta

wa'ātūalzzakāta wairka'ū ma'a alrrāki'ina)

Artinya: "Dan dirikanlah shalat, tunaikanlah zakat dan ruku'lah beserta orang-orang yang rukuk". (Al - Qur'an Departemen Agama Rl, 2007: 16)

Investasi sebagai bentuk pengelolahan dana guna memberikan keuntungan dengan cara menempatkan dana tersebut pada alokasi yang diperkirakan akan memberikan tambahan keuntungan.
Investasi dilakukan dengan beberapa tujuan berikut :

a. Terciptanya keberlanjutan (continuity) dalam investasi tersebut.

b. Terciptanya profit yang maksimum atau keuntungan yang diharapkan (profit actual)

c. Terciptanya kemakmuran bagi para pemegang saham

d. Turut memberikan andil bagi pembangunan bangsa

Penjelasan definisi dan tujuan investasi diatas adalah penjelasan definisi dan tijuan investasi secara umum. Menurut Ryandono (2009:70) dalam padangan Islam, investasi memiliki definisi dan tujuan yang lebih luas karena mencakup aspek dunia (materi) dan akhirat.

Kinerja merupakan suatu kondisi yang harus diketahui dan dikonfirmasikan kepada pihak tertentu untuk mengetahui tingkat pencapaian hasil suatu instansi dihubungkan dengan visi yang diemban suatu organisasi atau perusahaan serta mengetahui dampak positif dan negatif dari suatu kebijakan operasional. Faktorfaktor yang memengaruhi kinerja individu tenaga kerja, yaitu: kemampuan mereka, motivasi, dukungan yang diterima, keberadaan pekerjaan yang mereka lakukan, hubungan mereka dengan organisasi. Selain itu, ada faktor yang memengaruhi kinerja antara lain :

a. Faktor kemampuan secara psikologis kemampuan (ability) pegawai terdiri dari kemampuan potensi (IQ) dan kemampuan realita (pendidikan). Oleh karena itu pegawai perlu 
Fitri, et al/Jurnal Ekonomi Syariah Teori dan Terapan Vol. 3 No. 8 Agustus 2016: 625-642; PENGARUH RASIO PROFITABILITAS, RASIO SOLVABILITAS, DAN RASIO LIKUIDITAS TERHADAP RETURN SAHAM PERUSAHAAN PROPERTI DAN REAL ESTATE YANG TERDAFTAR DALAM INDEKS SAHAM SYARIAH INDONESIA (ISSI) PERIODE 2011 - 2014

dtempatkan pada pekerjaan yang sesuai dengan keahlihannya.

b. Faktor motivasi Motivasi terbentuk dari sikap (attiude) seorang pegawai dalam menghadapi situasi (situasion) kerja. Motivasi merupakan kondisi yang menggerakkan diri pegawai terarah untuk mencapai tujuan kerja. Sikap mental merupakan kondisi mental yang mendorong seseorang untuk berusaha mencapai potensi kerja secara maksimal.

Dasar hukum Islam tentang investasi terdapat dalam dalil Al - Qur'an dan Al Hadits berikut :

Dalil tentang Investasi :

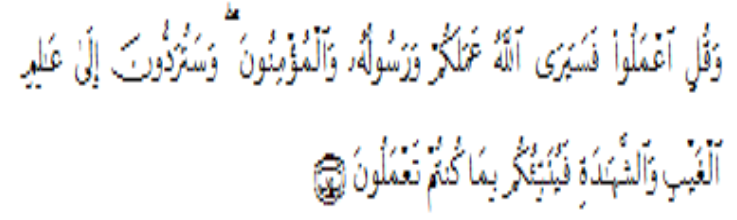

(waquli a'maluu fasayara Allahu a'malakun warasooluhu waalmuminoona wasaraddoona ila a'alimi alghaybi waalshshahadari faunabbiukum bima kuntum ta'maluna)

Dan Katakanlah: "Bekerjalah kamu, Maka Allah dan Rasul-Nya serta orang-orang mukmin akan melihat pekerjaanmu itu, dan kamu akan dikembalikan kepada (Allah) yang mengetahui akan yang ghaib dan yang nyata, lalu diberitakan-Nya kepada kamu apa yang telah kamu kerjakan." (QS. At - Taubah (Al Qur'an Departemen Agama Rl, 2007: 105)

Dalil tentang Kinerja :

Jadilah orang pertama, jangan menjadi orang kedua, apaagi yang ketiga. Barangsiapa yang hari ini lebih baik dari hari kemaren maka ia termasuk golongan yang beruntung. Barangsiapa yang hari ini sama dengan hari kemarin maka ia termasuk golongan yang merugi. Dan barangsiapa yang hari ini lebih buruk dari hari kemarin, maka ia termasuk golongan yang celaka. (HR. Thabrani)

Menurut Ryandono

(2009:70)

investasi syariah adalah pengorbanan sumber daya pada masa sekarang untuk mendapatkan hasil yang pasti, dengan harapan memperoleh hasil yang lebih besar di masa yang akan datang, baik langsung maupun tidak langsung seraya tetap berpijak pada prinsip-prinsip syariah secara menyeluruh (kaffah).

Salah satu bentuk investasi yang sesuai dengan syariah adalah membeli saham perusahaan, sebab investasi keuangan menurut syariah harus terkait secara langsung dengan suatu aset atau kegiatan usaha yang spesifik dan menghasilkan manfaat.

Definisi saham yang disampaikan oleh Bursa Efek Indonesia (BEI) adalah surat berharga sebagai bukti penyertaan atau pemilikan individu maupun institusi dalam suatu perusahaan (BEl, 2010:46). Definisi saham sebagai bukti penyertaan atau kepemilikan juga disampaikan oleh Suhartono dan Fadlillah yang memberikan penjelasan bahwa saham adalah tanda penyertaan atau kepemilikan seseorang atau badan usaha dalam suatu perusahaan atau perseroan terbatas. Memiliki saham berati memiliki perusahaan. Umumnya investor membeli saham karena prospek perusahaan, bila prospek perusahaan membaik maka harga saham juga akan meningkat. 
Fitri, et al/Jurnal Ekonomi Syariah Teori dan Terapan Vol. 3 No. 8 Agustus 2016: 625-642; PENGARUH RASIO PROFITABILITAS, RASIO SOLVABILITAS, DAN RASIO LIKUIDITAS TERHADAP RETURN SAHAM PERUSAHAAN PROPERTI DAN REAL ESTATE YANG TERDAFTAR DALAM INDEKS SAHAM SYARIAH INDONESIA (ISSI) PERIODE 2011 - 2014

Secara umum, investasi pada pasar modal di Indonesia mengacu pada keputusan DSN-MUI yang ditindak lanjuti dengan keputusan ketua Bapepam - LK. Fatwa DSN - MUI No: 40/DSN-MUI/X/2003 Pasal 3, tentang Pasar Modal dan Pedoman Umum Penerapan Prinsip Syariah di Bidang Pasar Modal, yaitu :

Emiten yang menerbitkan efek syariah pasal 3 kriteria emiten atau perusahaan publik.

1. Jenis usaha, produk barang, jasa yang diberikan dan akad serta cara pengelolaan perusahaan emiten atau perusahaan publik yang menerbitkan Efek Syariah tidak boleh bertentangan dengan prinsip - prinsip syariah.

2. Jenis kegiatan usaha yang bertentangan dengan prinsip - prinsip Syariah sebagaimana dimaksudkan dalam Pasal 3 No 1 diatas, antara lain

a. Perjudian dan permainan yang tergolong judi atau perdagangan yang dilarang

b. Lembaga keuangan konvensional (ribawi), termasuk perbankan atau asuransi konvensional

c. Produsen, distributor, serta pedagang makanan dan minuman yang haram

d. Produsen, distributor, dan atau penyedia barang - barang atau pun jasa yang merusak moral dan bersifat mudarat.

e. Melakukan investasi pada Emiten (perusahaan) yang pada saat transaksi tingkat (nisbah) hutang perusahaan kepada lembaga kevangan ribawi lebih dominan dari modalnya.

3. Emiten atau Perusahaan Publik yang bermaksud menerbitkan Efek Syariah wajib untuk menandatangani dan memenuhi ketentuan akad yang sesuai dengan syariah atak Efek Syariah yang dikeluarkan.

4. Emiten atau Perusahaan Publik yang menerbitkan Efek Syariah wajib menjamin bahwa kegiatan usahanya memenuhi prinsip - prinsip syariah dan memiliki Shariah Compliance Offficer.

Dalam hal Emiten atau Perusahaan Publik yang menerbitkan Efek Syariah sewaktu - waktu tidak memenuhi persyaratan tersebut diatas, maka Efek yang diterbitkan dengan sendirinya sudah bukan sebagai Efek Syariah. Kriteria DSN MUI tersebut menindaklanjuti dengan keputusan ketua Bapepam - LK No: KEP.130/BL/2006 Tentang Penerbitan Efek Syariah dengan lampiran pada Angka 2 huruf a Peraturan IX.A.13 adalah :

1. Ketentuan Umum

a. Kegiatan usaha yang bertentangan dengan prinsip prinsip Syariah antara lain :

1. Perjudian dan permainan yang tergolong judi atau perdagangan yang dilarang.

2. Menyelenggarakan jasa keuangan yang menerapkan konsep ribawi, jual - beli risiko yang mengandung gharar atau maysir. 
Fitri, et al/Jurnal Ekonomi Syariah Teori dan Terapan Vol. 3 No. 8 Agustus 2016: 625-642; PENGARUH RASIO PROFITABILITAS, RASIO SOLVABILITAS, DAN RASIO LIKUIDITAS TERHADAP RETURN SAHAM PERUSAHAAN PROPERTI DAN REAL ESTATE YANG TERDAFTAR DALAM INDEKS SAHAM SYARIAH INDONESIA (ISSI) PERIODE 2011 - 2014

3. Memproduksi, mendistribusikan, memperdagangkan, dan menyediakan :

a. Barang dan atau jasa yang haram karena zatnya (haram lidzatihi)

b. Barang dan atau jasa yang haram bukan karena zatnya (haram li-dzatihi) yang ditetapkan oleh DSN - MUI

c. Barang dan atau jasa yang merusak moral dan bersifat mudarat.

4. Melakukan Investasi pada perusahaan yang pada saat transaksi tingkat (nisbah) hutang perusahaan kepada lembaga keuangan ribawi lebih dominan dari modalnya, kecuali investasi tersebut dinyatakan kesyariahannya oleh DSN - MUI.

Peraturan Bapepam - LK No: KEP.130/BL/2006 ditindaklanjuti dengan peraturan NO : KEP-314/BL/2007 tentang kriteria dan peerbitan Daftar Efek Syariah yang dimuat dalam Peraturan II.K.1, yaitu tidak melebihi rasio - rasio kevangan sebagai berikut:

a. Total hutang berbasis bunga dibandingkan dengan total ekuitas tidak lebih dari $82 \%$ (hutang yang berbasis bunga dibandingkan dengan total ekuitas tidak lebih dari $45 \%, 55 \%$ )

b. Total pendapatan bunga dan pendapatan tidak halal lainnya dibandingkan total pendapatan (revenue) tidak lebih dari $10 \%$.
ISSI merupakan indeks saham yang mencerminkan keseluruhan saham syariah yang tercatat di Bursa Efek Indonesia (BEI) dan Daftar Efek Syariah (DES). Konstituen direview setiap 6 bulan sekali ( Mei dan November) dan dipublikasikan pada awal bulan berikutnya. Konstituen ISSI juga dilakukan penyesuaian apabila ada saham syariah yang baru tercatat atau dihapuskan dari DES. Metode perhitungan indeks ISSI menggunakan rata - rata tertimbang dari kapitalisasi pasar. Tahun dasar yang digunakan dalam perhitungan ISSI adalah awal penerbitan DES yaitu Desember 2007. Indeks ISSI diluncurkan pada tanggal 12 Mei 2011 . (sumber : Bursa Efek Indonesia, diakses 05 April 2015)

Hadirnya ISSI diharapkan dapat mempermudah perusahaan sekuritas dalam melahirkan produk investasi baru berbasis syariah.menurut Direktur Pengembangn Bursa Efek Indonesia, salah satu latar belakang hadirnya indeks tersebut adalah untuk menjawab kebutuhan pasar terhadap indikator yang mampu menggambarkan kinerja seluruh saham syariah yang tercatat di BEl. Dengan adanya ISSI, emiten juga akan mendapatkan keuntungan lebih, seperti dalam penambahan modal baik ritel maupun institusi.

Setidaknya terdapat 214 saham yang masuk dalam ISSI pada saat awal peresmian di tahun 2011. Berdasarkan perhitungan yang dilakukan oleh pihak BEI, 214 saham tersebut berkapitalisasi sebesar RP.1.804 triliun atau $43.6 \%$ dari total kapitalisasi Pasar Modal yang pada saat 
Fitri, et al/Jurnal Ekonomi Syariah Teori dan Terapan Vol. 3 No. 8 Agustus 2016: 625-642; PENGARUH RASIO PROFITABILITAS, RASIO SOLVABILITAS, DAN RASIO LIKUIDITAS TERHADAP RETURN SAHAM PERUSAHAAN PROPERTI DAN REAL ESTATE YANG TERDAFTAR DALAM INDEKS SAHAM SYARIAH INDONESIA (ISSI) PERIODE 2011 - 2014

itu (tahun 211) mencapai Rp.3.405 triliun (Sumber: okezone.com)

Return saham adalah tingkat keuntungan yang dinikmati oleh pemodal atas suatu investasi saham yang dilakukannya. Setiap investasi baik jangka pendek maupun jagka panjang mempunyai tujuan utama untuk mendapatkan keuntungan yang disebut return, baik langsung maupun tidak langsung.

Return dapat berupa return realisasi yang sudah terjadi atau return yang belum terjadi tetapi diharapkan dimasa mendatang. Disisi lain, return pun memiliki peran yang amat signifikan didalam menentukan nilai dari sebuah saham. Return merupakan hasil yang diperoleh dari investasi yang berupa return realisasi (realized return) dan return ekspektasi (expected return). Return realisasi merupakan return yang telah terjadi yang dihitung berdasarkan data historis dan digunakan sebagai salah satu pengukur kinerja perusahaan. Return realisasi ini juga berguna sebagai dasar penentuan return ekspektasi (expected return) yang merupakan return yang diharapkan oleh investor di masa mendatang. Return realisasi diukur dengan menggunakan return total (total return), relatif return (return relative), kumulatif return (return cumulative), dan return disesuaikan (adjusted return). Return total merupakan return keseluruhan dari suatu investasi dalam suatu periode tertentu dari capital gain /loss dan yield. Return saham yang tinggi mengindikasi bahwa saham tersebut aktif diperdagangkan.

Return terdiri dari capital gain (loss) dan yield :

Return Total $=$ Capital gain $($ loss $)+$ Yield

Capital gain (loss) merupakan selisih harga investasi sekarang relatif dengan harga periode lalu :

Capital gain (loss) $=\frac{\mathrm{p}_{t}-\mathrm{p}_{t-1}}{\mathrm{p}_{t-1}}$

Keterangan :

$P_{t} \quad$ : Harga saham periode sekarang

$P_{t-1} \quad$ : Harga saham periode berikutnya

Yield merupakan persentase

penerimaan kas periodik terhadap harg investasi periode tertentu dari suatu investasi, dan untuk saham biasa dimana pembayaran periodik sebesar $D_{t}$ rupiah per lembar, maka yield dapat ditulisakan sebagai be

Yield $=\frac{D_{t}}{P_{t}-1}$

Keterangan :

$D_{t} \quad$ : Dividen kas yang dibayarkan

$P_{t-1}$ : Harga saham periode sebelumnya

Sehingga return total dapat dirumuskan sebagai berikut : (Jogiyanto, 1998)

Return Total $=\frac{\mathrm{p}_{t}-\mathrm{p}_{t-1}}{\mathrm{p}_{t-1}}+\frac{D_{t}}{P_{t-1}}=\frac{P_{t}-P_{t-1}+D_{t}}{P_{t-1}} \ldots . .2 .3$

Keterangan :

$P_{t} \quad$ : Harga saham sekarang

$P_{t-1} \quad$ : Harga saham periode berikutnya

$D_{t} \quad$ : Dividen kas yang dibayarkan

Namun mengingat tidak selamanya perusahaan membagikan dividen kas secara periodik kepada pemegang sahamnya, maka return saham 
Fitri, et al/Jurnal Ekonomi Syariah Teori dan Terapan Vol. 3 No. 8 Agustus 2016: 625-642; PENGARUH RASIO PROFITABILITAS, RASIO SOLVABILITAS, DAN RASIO LIKUIDITAS TERHADAP RETURN SAHAM PERUSAHAAN PROPERTI DAN REAL ESTATE YANG TERDAFTAR DALAM INDEKS SAHAM SYARIAH INDONESIA (ISSI) PERIODE 2011 - 2014

dapat diitung sebagai berikut : (Jogiyanto, 1998)

Return Saham $=\frac{\mathrm{p}_{t}-\mathrm{p}_{t-1}}{\mathrm{p}_{t-1}}$

Keterangan :

$P_{t} \quad$ : Harga saham periode sekarang

$P_{t-1} \quad$ : Harga saham periode berikutnya

Rasio Keuangn adalah hubungan

yang dihitung dan informasi keuangan

suatu perusahaan dan digunakan untuk tujuan perbandingan. analisis rasio kevangan merupakan analisis dengan membandingkan satu pos laporan dengan pos laporan keuangan lainnya, baik secara individu maupun bersama sama untuk mengetahui hubungan diantara pos tertentu, baik dalam neraca maupun dalam laporan laba rugi. Rasio menggambarkan suatu hubungan dan perbandingan antara jumlah tertentu dalam satu pos laporan keuangan dengan jumlah yang lain pada pos laporan keuangan yang lain. Dengan menggunakan metode analisis serupa berupa rasio ini akan menjelaskan atau memberikan gambaran tentang baik atau buruknya keadaan atau posisi keuangan suatu perusahaan. Dengan rasio keuangan pula dapat membantu perusahaan dalam mengidentifikasi kekuatan dan kelemahan keuangan sebuah perusahaan.

ROA merupakan rasio profitabilias yang digunakan untuk mengukur efektifitas perusahaan didalam menghasilkan keuntungan dengan memanfaatkan aktiva yang dimilikinya. Menurut Ratna (2009) ROA merupakan rasio antara pendapatan bersih sesudah pajak (Net Income After Tax - NIAT) terhadap total asset. Secara matematis ROA dapat diformulasikan sebagai berikut :

$\mathrm{ROA}$

$=$

$\frac{\text { NIAT }}{\text { TOT ALASSET }}$

Keterangan :

NIAT : Net Income After Tax (laba bersih setelah pajak)

Eve. Total Assets : Rata - rata total aktiva (assets) yang diperoleh dari rata - rata total aset awal tahun dan akhir tahun

DER mencerminkan kemampuan perusahaan dalam memenuhi kewajibannya yang ditunjukkan oleh beberapa bagian dari modal sendiri atau ekuitas yang digunakan untuk membayar hutang. DER merupakan perbandingan antara total hutang yang dimiliki perusahaan dengan total ekuitasnya. Secara matematis DER diformulasikan sebagai berikut :

DER $=\frac{\text { TotalDebt }}{\text { TotalShareholder'sEquity }}$.

Keterangan :

Total Debt :total liabilities (hutang jangka pendek maupun hutang jangka panjang) Total Shareholder's Equity : total modal sendiri yang dimiliki perusahaan.

Likuiditas

perusahaan

menggambarkan kemampuan perusahaan dalam memenuhi kewajiban jangka pendeknya (Utomo, 2004). Untuk mengukur likuiditas perusahaan dalam penelitian ini menggunakan rasio current ratio (CR). CR merupakan salah satu ukuran likuiditas bertujuan untuk mengukur kemampuan perusahaan untuk melunasi 
Fitri, et al/Jurnal Ekonomi Syariah Teori dan Terapan Vol. 3 No. 8 Agustus 2016: 625-642; PENGARUH RASIO PROFITABILITAS, RASIO SOLVABILITAS, DAN RASIO LIKUIDITAS TERHADAP RETURN SAHAM PERUSAHAAN PROPERTI DAN REAL ESTATE YANG TERDAFTAR DALAM INDEKS SAHAM SYARIAH INDONESIA (ISSI) PERIODE 2011 - 2014

kewajiban jangka pendeknya dengan aktiva lancar yang dimilikinya. Rasio ini dihitung dengan membagi aktiva lancar dengan kewajiban jangka pendeknya. Rasio ini sering disebut dengan rasio modal kerja yang menunjukkan jumlah aktiva lancar yang tersedia yang dimiliki oleh perusahaan untuk merespon kebutuhan kebutuhan bisnis dan meneruskan kegiatan bisnis hariannya. CR merupakan alat ukur bagi kemampuan likuiditas (solvabilitas jangka pendek) yaitu kemampuan untuk membayar hutang yang segera harus dipenuhi dengan aktiva lancar. Sehingga secara matematis CR dirumuskan sebagai berikut :

Current Ratio $=\frac{\text { CurrentAssets }}{\text { CurrentLiabilities }}$

Keterangan :

Current Assets : Aset Lancar (kas, surat berharga, piutang, dan persediaan)

Current Liabilities : Utang Lancar (Utang pajak, utang bunga, uang wesel, utang gaji, dan utang jangka pendek lainnya.

\section{METODE PENELITIAN}

Pendekatan yang akan digunakan dalam penelitian ini adalah pendekatann kuantitatif.

\section{Identifikasi Variabel}

1. Variabel bebas ( independent variable )

Menurut Sugiyono (2009:39), variabel bebas adalah veriabel yang mempengaruhi atau yang menjadi sebab perubahan atau timbulnya veriabel dependen ( terikat). Variabel bebas pada penelitian ini terdiri dari tiga faktor yang mempengaruhi return saham, antara lain :

a. Return on Assets atau ROA ( $X_{1}$ )

b. Debt to Equity Ratio atau DER $\left(X_{2}\right)$

C. Current Ratio atau CR $\left(X_{3}\right)$

\section{Variabel Terikat (dependent variable)}

Menurut Sugiyono (2009:39),

variabel terikat merupakan variabel yang dipengaruhi atau yang menjadi akibat, karena adanya variabel bebas \ Variabel bebas dalam penelitian ini adalah return saham (Y).

\section{jenis dan Sumber Data}

Data sekunder merupakan data primer yang dieroleh oleh piha lain atau data yang telah diolah lebih lanjut dan disajikan oleh pengumpul data atau pihak lain yang umumnya berupa tabel atau diagram. Data sekunder yang digunakan dalam penelitian ini berupa laporan keuangan yang didalamnya terdapat Return on Asset, Debt to Equity Ratio dan Current Ratio tahunan perusahaan properti dan real estate yang terdaftar dalam Indeks Saham Syariah Indonesia periode $2011-2014$.

Menurut Sugiyono ( 2009: 137 ), sumber data sekunder yaitu sumber data yang tidak langsung memberikan data kepada pengumpul data. Data sekunder dapat diperoleh dari studi kepustakaan dan literature lain baik majalah, artikel, maupun internet yang berhubungan dengan Return on Asset, Debt to Equity Ratio dan Current Ratio yang dapat mempengaruhi return saham. 
Fitri, et al/Jurnal Ekonomi Syariah Teori dan Terapan Vol. 3 No. 8 Agustus 2016: 625-642; PENGARUH RASIO PROFITABILITAS, RASIO SOLVABILITAS, DAN RASIO LIKUIDITAS TERHADAP RETURN SAHAM PERUSAHAAN PROPERTI DAN REAL ESTATE YANG TERDAFTAR DALAM INDEKS SAHAM SYARIAH INDONESIA (ISSI) PERIODE 2011 - 2014

\section{Regresi Data Panel}

Regresi dengan menggunakan data panel disebut model regresi data panel. Ada beberapa keuntungan yang diperoleh dengan menggunakan data panel. Pertama, data panel yang merupakan gabungan dua data yaitu time series (selama beberapa tahun tertentu) dan cross section (pada beberapa perusahaan tertentu) yang mampu menyediakan data yang lebih banyak sehingga akan menghasilkan degree of freedom yang lebih besar (Gujarati, 2003:636). Kedua, menggabungkan informasi dari data time series dan cross section dapat mengatasi masalah yang timbul ketika ada masalah penghilangan variabel (omitted-variabel) . Untuk mengatasi interkorelasi diantara variabel - variabel bebas yang pada akhirnya dapat mengakibatkan tidak tepatnya penafsiran regresi, metode data panel lebih tepat digunakan (Griffith, 2001:351).

Gujarati (2003:637), menambahkan bahwa terdapat beberapa keuntungan dalam menggunakan data panel, yaitu:

1. Dengan mengkombinasikan data time-series dan data cross-sectional, data panel memberikan data yang lebih informatif, lebih variatif, mengurangi kolinearitas antar variabel, derajat kebebasan yang lebih banyak, dan efisiensi yang lebih besar.

2. Dengan mempelajari bentuk crosssectional berulang-ulang dari observasi, datapanel lebih baik untuk mempelajari dinamika perubahan.

3. Data panel dapat mendeteksi lebih baik dalam mengukur efek-efek yang tidakdapat diobservasi dalam crosssectional maupun data time-series murni.

4. Data panel memungkinkan untuk dipelajarinya model perilaku yang lebih rumit.

\section{HASIL DAN PEMBAHASAN}

Data rasio keuangan dari empat belas sampel emiten tersebut kemudian diolah menggunakan software Eviews 8.1 dengan teknik analisis regresi data panel untuk mengetahui pengaruh rasio keuangan tersebut. Namun sebelum teknik analisis tersebut dilakukan, analisis deskriptif dilakukan terlebih dahulu untuk menampilkan nilai keseluruhan masing masing variabel dari tiap emiten yang terdaftar di ISSI. Variabel tersebut adalah ROA, DER, dan CR.

\section{Deskripsi Data Return, ROA, DER, CR}

Nilai tertinggi dan terendah dari variabel ROA, DER, dan CR dapat dikatakan terpaut sangat jauh sehingga menunjukkan bahwa return saham para emiten yang terdaftar dalam Index Saham Syariah Indonesia (ISSI) tahun 2011-2014 mengalami pergerakan yang tidak menentu setiap tahunnya. Range dapat dikatakan lebar yang mengakibatkan varians data besar. Return nilai tertinggi sebesar 0.98013245, nilai terendahnya sebesar -0.724137931 dan nilai rataratanya sebesar 0.152136082 . Return on 
Fitri, et al/Jurnal Ekonomi Syariah Teori dan Terapan Vol. 3 No. 8 Agustus 2016: 625-642; PENGARUH RASIO PROFITABILITAS, RASIO SOLVABILITAS, DAN RASIO LIKUIDITAS TERHADAP RETURN SAHAM PERUSAHAAN PROPERTI DAN REAL ESTATE YANG TERDAFTAR DALAM INDEKS SAHAM SYARIAH INDONESIA (ISSI) PERIODE 2011 - 2014

Asset (ROA) memiliki nilai tertinggi sebesar 0.135727876, nilai terendahnya sebesar 0.041537989 dan nilai rata-ratanya sebesar 0.084242899. Debt to Equity Ratio (DER) memiliki nilai tertinggi sebesar 1.798828058 , nilai terendahnya sebesar 0.215765716 dan nilai rata-ratanya sebesar 0.830333962 . Current Ratio (CR) memiliki nilai tertinggi sebesar 1.832288587, nilai terendahnya sebesar 0.240502703 dan nilai rata-ratanya sebesar 1.087903414 .

\section{Deskripsi Return on Asset (ROA)}

Nilai ROA tertinggi yaitu pada tahun 2014 sebesar 0.135727876 , sedangkan nilai terendah ROA pada tahun 2014 yaitu sebesar 0.041537989, dan rata - rata nilai ROA sebesar 0,08424 . Nilai tertinggi ROA dari tahun 2011 - 2014 dimiliki oleh PT Roda Vivatex Tbk, sedangkan nilai terendah ROA dari tahun 2011 - 2014 dimiliki oleh PT Agung Podomoro Land Tbk.

\section{Deskripsi Debt to Equity Ratio (DER)}

Nilai DER tertinggi yaitu pada tahun 2014 yaitu sebesar 1.798828058 , sedangkan nilai DER terendah yaitu pada tahun 2014 sebesar 0,215765716, dan rata - rata nilai DER yaitu 0.90194 . nilai DER tertinggi dari tahun 2011 2014 dimiliki PT Agung Podomoro Land Tbk, sedangkan nilai terendah DER dari tahun 2011 - 2014 dimiliki oleh PT Roda Vivatex Tbk.

\section{Deskripsi Current Ratio (CR)}

Nilai tertinggi $C R$ yaitu pada tahun 2014 sebesar 1.832288587, sedangkan nilai terendah CR yaitu pada tahun 2013 sebesar 0.240502703 , dan rata - rata CR yaitu 1,1362275. Nilai CR tertinggi dari tahun 2011 2014 dimiliki PT Agung Podomoro Land Tbk, dan nilai CR terendah dari tahun 2011 - 2014 dimiliki oleh PT Roda Vivatex Tbk.

\section{Uji Chow}

Keputusan HO ditolak jika P-Value < a (0.05 atau 5\%). Berdasarkan output dari Eviews diperoleh P-Value ( Prob. Cross Section F) sebesar 0.4054. Karena P-Value $>$ a yakni $0.4054>0.05$ maka diputuskan untuk menerima $\mathrm{HO}$, artinya Return on Asset (ROA), Debt to Equity Ratio (DER), dan Current Ratio (CR) pada model ini tidak ada efek secara bersama - sama sehingga model yang sesuai adalah PLS.

Model PLS memberikan nilai RSquared sebesar 10,89\% seperti yang ditunjukkan output diatas. Artinya variabel independen dapat menjelaskan variabilitas dependen sebesar 10,89\%, sedangkan sisanya $89,11 \%$ dijelaskan oleh variabel lain yang belum masuk dalam model.

\section{Uji Multikolineritas}

Dari hasil uji multikol, HO ditolak karena nilai VIF < 10. Jadi tidak ada multikolineritas atau bebas dari penyimpangan.

\section{Uji Heteroskedastisitas}

Dari hasil uji heteroskedastisitas, nilai prob > Chi2 lebih dari 0,05, jadi HO ditolak. Artinya nilai estimator (koefisien regresi) dari model ini efisien, bias dan konsisten. 
Fitri, et al/Jurnal Ekonomi Syariah Teori dan Terapan Vol. 3 No. 8 Agustus 2016: 625-642; PENGARUH RASIO PROFITABILITAS, RASIO SOLVABILITAS, DAN RASIO LIKUIDITAS TERHADAP RETURN SAHAM PERUSAHAAN PROPERTI DAN REAL ESTATE YANG TERDAFTAR DALAM INDEKS SAHAM SYARIAH INDONESIA (ISSI) PERIODE 2011 - 2014

\section{Uji Autokorelasi}

Berdasarkan hasil uji autokorelasi, nilai prob > F lebih dari 0,05 , jadi $\mathrm{HO}$ ditolak. Artinya nilai varian efisien sehingga hasil tes signifikansi menjadi akurat.

\section{Uji t- Statistik}

a. Variabel ROA : HO ditolak, bisa disimpulkan bahwa ROA berpengaruh signifikan secara parsial terhadap return saham.

b. Variabel DER : HO diterima, bisa disimpulkan bahwa DER berpengaruh tidak signifikan secara parsial terhadap return saham.

c. Variabel CR : HO diterima, bisa disimpulkan bahwa CR berpengaruh tidak signifikan secara parsial terhadap return saham.

\section{Uji F-Statistik}

Nilai F-hitung adalah 2.1186 dan nilai probability $F$ yang dihasilkan yakni 0.1090 yang lebih dari $a=0,05(5 \%)$, artinya pada pengujian ini dapat disimpulkan bahwa variabel ROA, DER, dan CR tidak berpengaruh secara serentak (simultan) terhadap return saham para emiten Indeks Saham Syariah Indonesia ( ISSI ).

\section{Uji $\boldsymbol{R}^{2}$ (R-Square)}

Model PLS memberikan nilai $R$ Squared sebesar $10.89 \%$ seperti yang ditunjukkan output diatas. Artinya variabel independen dapat menjelaskan variabilitas dependen sebesar $10.89 \%$ sedangkan sisanya
$89.11 \%$ dijelaskan oleh variabel lain yang belum masuk dalam model.

\section{SIMPULAN}

Berdasarkan pembahasan hasil penelitian yang telah dilakukan, maka simpulan yang dapat diambil dalam penelitian ini adalah :

1. Variabel independen Return on Asset (ROA), Debt to Equity Ratio (DER), dan Current Ratio (CR) secara simultan berpengaruh tidak signifikan terhadap variabel dependen yaitu return saham syariah perusahaan properti dan real estate yang terdaftar di Indeks Saham Syariah Indonesia (ISSI) pada tingkat signifikansi $5 \%$. Hal ini ditunjukkan dari nilai probability $F$ yang di hasilkan yakni 0.257572 yang lebih dari $a=0.05$ (5\%).

2. Variabel independen Return on Asset (ROA), Debt to Equity Ratio (DER), dan Current Ratio (CR) secara parsial masing - masing memiliki pengaruh sebagai berikut :

a. Return on Asset (ROA) memberikan pengaruh positif yang signifikan terhadap perubahan return saham syariah perusahaan properti dan real estate yang terdaftar di Indeks Saham Syariah Indonesia (ISSI) yang ditunjukkan dengan tingkat signifikansi sebesar 0.0386 (dibawah 0.05) pada tingkat signifikansi $5 \%$.

b. Debt to Equity Ratio (DER) memberikan pengaruh negatif 
Fitri, et al/Jurnal Ekonomi Syariah Teori dan Terapan Vol. 3 No. 8 Agustus 2016: 625-642; PENGARUH RASIO PROFITABILITAS, RASIO SOLVABILITAS, DAN RASIO LIKUIDITAS TERHADAP RETURN SAHAM PERUSAHAAN PROPERTI DAN REAL ESTATE YANG TERDAFTAR DALAM INDEKS SAHAM SYARIAH INDONESIA (ISSI) PERIODE 2011 - 2014

yang tidak signifikan terhadap perubahan return saham syariah perusahaan properti dan real estate yang terdaftar di Indeks Saham Syariah Indonesia (ISSI) yang ditunjukkan dengan tingkat signifikansi sebesar 0.4565 (diatas 0.05) pada tingkat signifikansi $5 \%$.

c. Current Ratio (CR) memberikan pengaruh positif yang tidak signifikan terhadap perubahan return saham syariah perusahaan properti dan real estate yang terdaftar di Indeks Saham Syariah Indonesia (ISSI) yang ditunjukkan dengan tingkat signifikansi sebesar 0.3142 (diatas 0.05) pada tingkat signifikansi $5 \%$.

\section{DAFTAR PUSTAKA}

Al - Quran Al - Karim, 2007. Terjemahan.

Departemen Agama Indonesia.

Gujarati, Damodar. 2003. Ekonometrika

Dasar. Edisi Terjemahan. Jakarta :

Erlangga.

Ryandono, Muhammad Nafik. 2009. Bursa

Efek dan Investasi Syariah. Jakarta: Serambi.

Sugiyono, 2009. Metode Penelitian

Kuantitatif, Kualitatif, R\&D. Edisi Kedua

Belas. Bandung : Alfabeta.

www.bapepam.go.id diakses tanggal 12

Oktober 2015

www.idx.co.id diakses tanggal 17

Desember 2015 